\title{
Analisis Kelayakan Ekonomi dan Finansial Pembangunan Jalan Tol Pandaan - Malang
}

\author{
Nur Fajar Aprilia Sari, Hera Widyastuti \\ Departemen Teknik Sipil, Fakultas Teknik Sipil, Lingkungan, dan Kebumian, \\ Institut Teknologi Sepuluh Nopember (ITS) \\ e-mail: hera.widyastuti@yahoo.co.uk
}

\begin{abstract}
Abstrak-Pembangunan Jalan Tol Pandaan - Malang memerlukan pertimbangan ekonomi dan finansial untuk menghindari adanya penanaman modal yang terlalu besar. Analisis kelayakan ini sangat penting bagi masyarakat pengguna jalan, pemerintah, dan investor. Pertimbangan ekonomi dibutuhkan untuk mengetahui manfaat dari adanya Jalan Tol Pandaan - Malang terhadap masyarakat sekitar, sedangkan pertimbangan finansial dibutuhkan sebagai acuan dalam investasi agar jalan tol ini merupakan perencanaan yang efisien. Oleh karena itu perlu dilaksanakan analisis kelayakan dari adanya Jalan Tol Pandaan - Malang agar mengetahui apakah jalan tol ini layak untuk dibangun. Pada studi ini, akan dianalisis kelayakan Jalan Tol Pandaan - Malang dengan merekapitulasi data-data volume kendaraan di jalan eksisting, yaitu jalan dari Kecamatan Pandaan sampai Kota Malang dengan pembagian ruas tertentu yang nantinya akan memberikan pengaruh terhadap jalan tol rencana. Data-data ini berupa data sekunder dari survey traffic counting, yang didapatkan dari Laboratorium Perhubungan Departemen Teknik Sipil ITS. Kemudian menghitung derajat kejenuhan dari jalan eksisting sebelum dibangun Jalan Tol Pandaan Malang untuk mengetahui kinerja lalu lintas jalan tersebut. Setelah itu dilakukan perhitungan untuk mengetahui presentase perpindahan kendaraan dari jalan eksisting ke Jalan Tol Pandaan - Malang dengan analisis trip assignment menggunakan 3 metode, yaitu Metode Smock, Metode Davidson, dan Metode JICA I. Namun akhirnya menggunakan Metode Smock dikarenakan banyak pertimbangan. Dari analisis trip assignment, maka didapatkan volume kendaraan yang akan melewati jalan tol rencana sehingga dapat menghitung derajat kejenuhan dari jalan tol rencana. Dari hasil analisis, didapatkan untuk kelayakan ekonomi BCR sebesar 2,796 > 1 dan nilai NPV sebesar Rp. 15.531.872.832.729 > 0. Untuk kelayakan finansial didapatkan nilai BCR sebesar 2,938 > 1, nilai NPV sebesar Rp. 16.760.098.491.986 > 0 dan nilai IRR sebesar 11,926\% > 4,86\% (MARR). Serta waktu Payback Period selama 17 tahun 6 bulan 22 hari. Berdasarkan hasil tersebut maka dapat disimpulkan pembangunan Jalan Tol Pandaan - Malang dikatakan layak dari segi ekonomi dan finansial.
\end{abstract}

Kata Kunci-Studi Kelayakan, Analisis Ekonomi, Analisis Finansial, Jalan Tol Pandaan - Malang.

\section{PENDAHULUAN}

$\mathrm{J}$ AWA Timur merupakan provinsi yang sangat padat dengan jumlah penduduk sebesar 39.075.152 jiwa [1], dimana Jawa Timur memiliki jumlah penduduk terbanyak kedua di Indonesia setelah Provinsi Jawa Barat [2]. Hal itu membuat Jawa Timur memiliki peranan yang sangat penting dalam perkembangan ekonomi di Indonesia. Di sisi lain, penguatan sendi perekonomian bangsa juga tidak terlepas dari menguatnya perekonomian pada berbagai aktivitas yang mulai menunjukkan perkembangan cukup pesat, yang mana dengan perkembangan ekonomi yang sangat cepat maka tingkat mobilitas orang, barang, dan atau jasa yang ada di Provinsi Jawa Timur akan terus meningkat, sehingga hal yang perlu diperhatikan akibat meningkatnya mobilitas orang, barang, dan jasa adalah transportasi.

Selain dalam segi perekonomian industri, Jawa Timur juga merupakan daerah yang mendapatkan pendapatan besar dari segi pariwisata. Daerah yang memiliki wisatawan terbanyak adalah Kota Malang. Kota Malang tercatat memiliki jumlah kunjungan di tahun 2015 sebanyak 3.251.367 juta orang, sedangkan jumlah kunjungan wisatawan di tahun 2016 mencapai 5.849.544 juta orang [3]. Dengan adanya perkembangan pariwisata di Kota Malang tersebut, maka hal yang perlu diperhatikan adalah transportasi. Hal itu dikarenakan apabila akses transportasi menuju ke daerah pariwisata itu mudah, cepat, dan nyaman maka wisatawan pun banyak yang mengunjungi daerah pariwisata tersebut sehingga dapat meningkatkan perekonomian di daerahnya.

Dari permasalahan kemacetan yang terjadi pada jalur yang menghubungkan Kecamatan Pandaan dan Kota Malang, tentu menimbulkan berbagai dampak negatif ditinjau dari berbagai segi, baik segi perekonomian daerah karena terhambatnya distribusi barang industri dan pariwisata, serta dari segi ekonomi bagi penumpang kendaraan karena waktu tempuh perjalanan yang lama dan biaya operasional kendaraan karena seringnya kendaraan berhenti di jalan. Oleh karena itu, untuk mengatasi kemacetan pada jalan penghubung Kecamatan Pandaan dengan Kota Malang dan untuk mendukung peningkatan perekonomian di Jawa Timur, pemerintah pusat dalam hal ini Badan Pengatur Jalan Tol (B.P.J.T) mempertimbangkan perlunya pembangunan Jalan Tol Pandaan - Malang. Jalan tol ini dibagi menjadi lima seksi, yaitu Seksi 1 (Pandaan - Purwodadi), Seksi 2 (Purwodadi Lawang), Seksi 3 (Lawang - Singosari), Seksi 4 (Singosari Pakis), dan Seksi 5 (Pakis - Malang).

Untuk menghindari adanya penanaman modal yang terlalu besar dalam pembangunan proyek ini, maka perlu dilakukannya studi tentang kelayakan dari proyek jalan tol ini. Analisis kelayakan ini sangat penting bagi masyarakat pengguna jalan, pemerintah, dan investor. Pada proyek pembangunan Jalan Tol Pandaan - Malang ini sudah terdapat studi tentang kelayakannya yang dibuat oleh Silasafitri Ciptoningjati, mahasiswa Departemen Teknik Sipil Institut Teknologi Sepuluh Nopember angkatan 2009 dengan judul "Analisis Kelayakan Pembangunan Jalan Tol Pandaan Malang" pada tahun 2013. Namun, karena adanya perubahan desain yang terjadi selama berjalannya proses pembangunan dari tahun 2016 hingga tahun 2018 dan adanya perubahan antara RTA (Rencana Teknik Akhir) dengan rencana lapangan yang direalisasikan, maka perlu dilakukan studi kelayakan ulang yang ditinjau dari aspek ekonomi dan finansial. Diharapkan dengan adanya studi ini dapat diketahui tentang kelayakan manfaat dan investasinya.

Dalam menentukan kelayakan dari pembangunan Jalan Tol Pandaan - Malang ini ditentukan dari besarnya nilai Benefit Cost Ratio (BCR), Net Present Value (NPV), Payback 
Return, dan Internal Rate of Return (IRR). Pembangunan proyek dikatakan layak apabila nilai $\mathrm{BCR}>1$, nilai NPV $>0$, Payback Return < lama konsesi pembangunan, dan IRR > Discount Rate.

\section{METODOLOGI}

Urutan penyelesaian Studi ini dapat dilihat pada bagan alir di bawah ini:

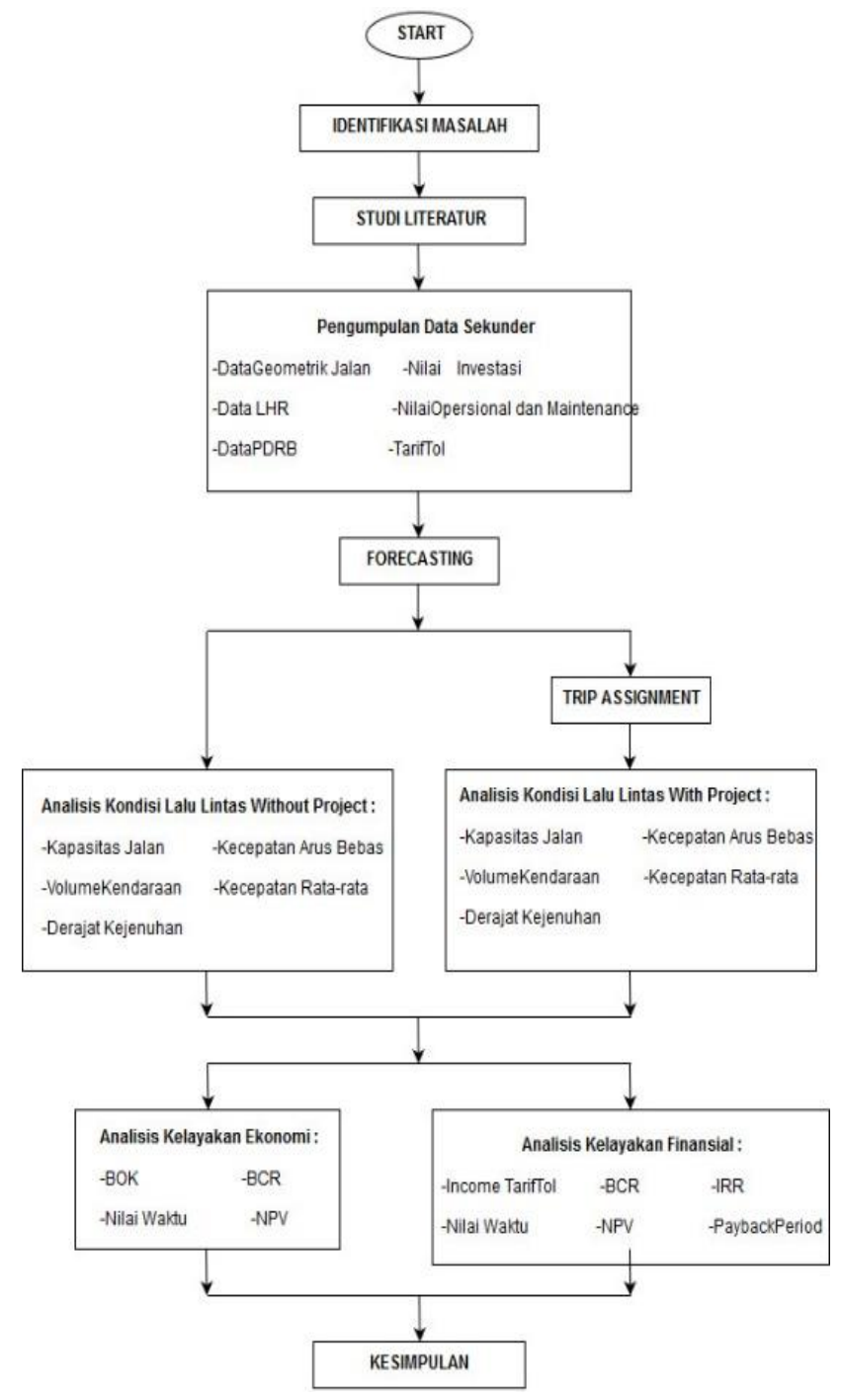

Gambar 1. Diagram alir penyelesaian studi.

\section{HASIL DAN PEMBAHASAN}

\section{A. Analisis Data Lalu Lintas}

Dari data Traffic Counting yang didapat dari Laboratorium Perhubungan Teknik Sipil Institut Teknologi Sepuluh Nopember akan digunakan untuk menganalisis kapasitas ruas jalan, volume kendaraan, dan derajat kejenuhan. Kapasitas jalan adalah jumlah kendaraan maksimum yang dapat melewati suatu jalur atau ruas jalan selama periode waktu tertentu dalam kondisi jalan raya dan arus lalu lintas tertentu [4]. Berikut ini adalah formula yang digunakan untuk menghitung kapasitas ruas :

$$
\mathrm{C}=\mathrm{C}_{0} * \mathrm{FC}_{\mathrm{LJ}} * \mathrm{FC}_{\mathrm{PA}} * \mathrm{FC}_{\mathrm{HS}}
$$

Dimana :

$\mathrm{C}=$ adalah kapasitas ( skr/jam )

$\mathrm{C}_{0}=\operatorname{kapasitas}$ dasar $(\mathrm{skr} / \mathrm{jam})$
$\mathrm{FC}_{\mathrm{LJ}}=$ adalah faktor penyesuaian kapasitas terkait lebar lajur atau jalur lalu lintas.

$\mathrm{FC}_{\mathrm{PA}}=$ adalah faktor penyesuaian kapasitas terkait pemisahan arah, hanya pada jalan tak terbagi.

$\mathrm{FC}_{\mathrm{HS}}=$ adalah faktor penyesuaian kapasitas terkait KHS pada jalan berbahu atau berkereb.

Sehingga didapatkan nilai kapasitas ruas dari masing-masing jalan eksisting dan jalan tol sebagaimana pada Tabel 1.

Tabel 1.

Kapasitas Ruas Jalan Eksisting dan Jalan Tol

\begin{tabular}{|c|c|c|c|c|c|c|}
\hline Jalan & $\mathrm{CO}$ & FCLJ & FCPA & FCHS & $\begin{array}{r}\mathrm{Ka} \\
(\mathrm{skr} / \mathrm{j} ;\end{array}$ & $\begin{array}{l}\text { astias }(\mathrm{C}) \\
\mathrm{m}) \text { (perlajur) }\end{array}$ \\
\hline Ruas A & 1900 & 1000 & 1000 & 0.93 & & 1767 \\
\hline Ruas B & 1900 & 1030 & 1000 & 0.93 & & 1820 \\
\hline Ruas C & 1900 & 1000 & 1000 & 0.93 & & 1767 \\
\hline Ruas D & 1900 & 1000 & 1000 & 0.93 & & 1767 \\
\hline Ruas E & 1900 & 1000 & 1000 & 0.93 & & 1767 \\
\hline Ruas F & 1900 & 1000 & 1000 & 0.93 & & 1767 \\
\hline Jalan Tol & 2300 & 1012 & - & - & & 2328 \\
\hline \multicolumn{7}{|c|}{ Keterangan: } \\
\hline \multicolumn{2}{|c|}{$\begin{array}{l}\text { Ruas A } \\
\text { (Sukorejo) }\end{array}$} & Jalan & Raya & Malang & - & Surabaya \\
\hline \multicolumn{2}{|c|}{ Ruas B } & \multicolumn{5}{|c|}{ = Jalan Raya Pasuruan (Purwosari) } \\
\hline \multicolumn{2}{|c|}{$\begin{array}{l}\text { Ruas C } \\
\text { (Purwodadi) }\end{array}$} & $=$ Jalan & Raya & Gempol & & Malang \\
\hline \multicolumn{2}{|c|}{ Ruas D } & \multicolumn{5}{|c|}{$=$ Jalan Raya Mondoroko (Singosari) } \\
\hline \multicolumn{2}{|l|}{ Ruas E } & \multicolumn{5}{|c|}{ = Jalan A. Yani Utara (Arjosari) } \\
\hline \multicolumn{2}{|c|}{ Ruas F } & \multicolumn{5}{|c|}{$=$ Jalan Letjend S. Parman } \\
\hline \multicolumn{2}{|c|}{ Jalan Tol } & \multicolumn{5}{|c|}{$=$ Jalan Tol Pandaan - Malang } \\
\hline
\end{tabular}

\section{B. Analisis Lalu Lintas Kondisi With Project}

Sedangkan untuk perhitungan derajat kejenuhan, maka menggunakan formula:

$$
\mathrm{Dj}=\mathrm{Q} / \mathrm{C}
$$

Dimana:

$$
\begin{aligned}
& \mathrm{Dj}=\text { Derajat Kejenuhan } \\
& \mathrm{Q}=\text { Arus Lalu Lintas (skr/jam) } \\
& \mathrm{C}=\text { Kapasitas jalan (skr/jam) }
\end{aligned}
$$

Sehingga didapatkan nilai derajat kejenuhan pada tahun 2019 dari masing-masing jalan eksisting sebagaimana pada Tabel 2.

Tabel 2.

Derajat kejenuhan Jalan Eksisting Without Project

\begin{tabular}{lccc}
\hline \hline Ruas Jalan & $\mathrm{Q}$ & $\mathrm{C}$ & $\mathrm{Dj}$ \\
\hline $\begin{array}{l}\text { Ruas A Arah } \\
\text { Malang-Pandaan }\end{array}$ & 2555 & 3534 & 0.723 \\
$\begin{array}{l}\text { Ruas A Arah } \\
\text { Pandaan-Malang } \\
\text { Ruas B Arah }\end{array}$ & 2834 & 3534 & 0.802 \\
$\begin{array}{l}\text { Malang-Pandaan } \\
\text { Ruas B Arah }\end{array}$ & 1810 & 3640 & 0.497 \\
$\begin{array}{l}\text { Pandaan-Malang } \\
\text { Ruas C Arah }\end{array}$ & 1846 & 3640 & 0.507 \\
$\begin{array}{l}\text { Malang-Pandaan } \\
\text { Ruas C Arah }\end{array}$ & 2546 & 3534 & 0.720 \\
$\begin{array}{l}\text { Pandaan-Malang } \\
\text { Ruas D Arah } \\
\text { Malang-Pandaan }\end{array}$ & 2039 & 3534 & 0.577 \\
$\begin{array}{l}\text { Ruas D Arah } \\
\text { Pandaan-Malang }\end{array}$ & 3516 & 3534 & 0.995 \\
$\begin{array}{l}\text { Ruas E Arah } \\
\text { Malang-Pandaan }\end{array}$ & 3436 & 3534 & 0.972 \\
$\begin{array}{l}\text { Ruas E Arah } \\
\text { Pandaan-Malang }\end{array}$ & 3231 & 3534 & 0.914 \\
$\begin{array}{l}\text { Ruas F Arah } \\
\text { Malang-Pandaan } \\
\text { Ruas F Arah } \\
\text { Pandaan-Malang }\end{array}$ & 3028 & 3534 & 0.857 \\
\hline \hline
\end{tabular}


Dari hasil perhitungan sesuai Tabel 2. terlihat bahwa beberapa ruas jalan eksisting sudah mendekati kondisi jenuh $(>0,75)$ dan bahkan ada yang melebihi kondisi jenuh. Maka selanjutnya dilakukan analisis pertumbuhan lalu lintas pada jalan eksisting dengan menggunakan data laju pertumbuhan yaitu data jumlah penduduk menurut kabupaten dan kota, data PDRB atas dasar harga konstan kabupaten dan kota, dan data PDRB perkapita atas dasar harga konstan kabupaten dan kota. Data-data tersebut digunakan sebagai acuan pertumbuhan kendaraan hingga tahun rencana.

Untuk mengetahui kecepatan kendaraan pada saat tidak ada hambatan atau $\mathrm{Dj}=0$, maka digunakan perhitungan Kecepatan Arus Bebas. Kecepatan arus bebas didefiniskan sebagai kecepatan rata-rata teoritis dari arus lalu lintas pada waktu kerapatan mendekati nol atau sama dengan nol, yaitu tidak ada kendaraan di jalan atau kecepatan suatu kendaraan yang tidak terpengaruh oleh kehadiran kendaraan lain (yaitu kecepatan dimana pengemudi merasa nyaman untuk bergerak pada kondisi geometrik, lingkungan, dan pengendalian lalu lintas yang ada pada suatu segmen jalan tanpa lalu lintas lain [4].

Bentuk umum persamaan untuk menentukan kecepatan arus bebas untuk jalan luar kota adalah:

$$
\mathrm{V}_{\mathrm{B}}=\left(\mathrm{V}_{\mathrm{BD}}+\mathrm{FV}_{\mathrm{B}, \mathrm{W}}\right) \times \mathrm{FV}_{\mathrm{B}, \mathrm{HS}} \times \mathrm{FV}_{\mathrm{B}, \mathrm{KFJ}}
$$

Dimana:

$\mathrm{VB}=$ adalah kecepatan arus bebas kendaraan ringan pada kondisi lapangan $(\mathrm{km} / \mathrm{jam})$

$\mathrm{V}_{\mathrm{BD}}=$ adalah arus bebas dasar kendaraan ringan pada jalan dan alinemen yang diamati ( $\mathrm{km} / \mathrm{jam})$

$\mathrm{FV}_{\mathrm{B}, \mathrm{W}}=$ adalah penyesuaian kecepatan akibat lebar jalan $(\mathrm{km} / \mathrm{jam})$

$\mathrm{FV}_{\mathrm{B}, \mathrm{HS}}=$ adalah faktor penyesuaian akibat hambatan samping dan lebar bahu jalan

$\mathrm{FV}_{\mathrm{B}, \mathrm{KFJ}}=$ adalah faktor penyesuaian kelas fungsi

Untuk kecepatan arus bebas tipe kendaraan lain dapat ditentukan dengan rumus berikut:

$$
\begin{aligned}
& V_{\mathrm{B}, \mathrm{KBM}}=\mathrm{V}_{\mathrm{BD}-} \mathrm{FV}_{\mathrm{B}} \times \mathrm{FV}_{\mathrm{B}, \mathrm{KBM}} / \mathrm{V}_{\mathrm{BD}} \\
& \text { Dimana, } \\
& \quad \mathrm{FV} \mathrm{B}_{\mathrm{B}}=\mathrm{V}_{\mathrm{BD}}-\mathrm{V}_{\mathrm{B}} \\
& \text { Keterangan: }
\end{aligned}
$$

$\mathrm{FV}_{\mathrm{B}} \quad=$ adalah faktor penyesuaian kecepatan arus bebas $\mathrm{KR}(\mathrm{km} / \mathrm{jam})$

$\begin{array}{lll}\mathrm{V}_{\mathrm{BD}} & = & \text { adalah kecepatan arus bebas dasar } \\ \mathrm{KR}(\mathrm{km} / \mathrm{jam}) & & \text { adalah kecepatan arus bebas } \mathrm{KR} \\ \mathrm{V}_{\mathrm{B}} & = & \end{array}$

$(\mathrm{km} / \mathrm{jam})$

$\mathrm{V}_{\mathrm{BD}, \mathrm{KBM}}=$ adalah kecepatan arus bebas dasar KBM, $(\mathrm{km} / \mathrm{jam})$

Dengan menggunakan data geometrik pada jalan eksisting dan jalan tol sebagai acuan menghitung kecepatan arus bebas, maka didapatkan kecepatan arus bebas setiap golongannya sebagaimana pada Tabel 3.

Tabel 3.

Kecepatan Arus Bebas Jalan Eksisting dan Jalan Tol

\begin{tabular}{lcccc}
\multicolumn{5}{c}{ Kecepatan Arus Bebas Jalan Eksisting dan Jalan Tol } \\
\hline \hline \multirow{2}{*}{ Ruas Jalan } & \multicolumn{4}{c}{ Kecepatan Arus Bebas (km/jam) } \\
\cline { 2 - 5 } & KR & KBM & BB & TB \\
\hline Ruas A & 74.147 & 61.789 & 76.999 & 58.937 \\
Ruas B & 76.048 & 63.373 & 78.973 & 60.448 \\
Ruas C & 74.147 & 61.789 & 76.999 & 58.937 \\
Ruas D & 74.147 & 61.789 & 76.999 & 58.937 \\
Ruas E & 74.147 & 61.789 & 76.999 & 58.937 \\
Ruas F & 74.147 & 61.789 & 76.999 & 58.937 \\
Jalan Tol & 88.800 & 70.636 & 90.818 & 65.591 \\
\hline \hline
\end{tabular}

Setelah didapatkan kecepatan arus bebas (Free Flow) untuk masing-masing tipe kendaraan di semua ruas jalan eksisting kemudian dianalisis kecepatan tempuh kendaraan dengan menggunakan grafik pada PKJI'14 hubungan derajat kejenuhan (DS) dengan tipe jalan masing-masing ruas jalan. Kecepatan tempuh kendaraan dianalisis pada kondisi without project pada jalan eksisting serta kondisi with project pada jalan eksisting dan jalan tol.

\section{Analisis Trip Assignment}

Trip Assignment merupakan salah satu cara yang digunakan untuk memprediksi persentase perpindahan kendaraan dari jalan eksisting ke Jalan Tol Pandaan - Malang saat jalan tol tersebut beroperasi pada tahun 2019. Untuk melakukan perhitungan analisis trip assignment, dilakukan beberapa metode, yaitu Metode JICA I, Metode Davidson, dan Metode Smock. Namun pada akhirnya memilih Metode Smock dengan parameter yang dianalisis melingkupi kecepatan, panjang jalan, waktu tempuh perjalanan (TT), dan kapasitas jalan (C), sebelumnya diperlukan adanya pembagian zona untuk mengetahui perpindahaan kendaraan yang terjadi di jalan tol rencana. Dalam studi ini terbagi menjadi 5 seksi sesuai dengan data perencanaan Jalan Tol Pandaan - Malang. Berikut adalah langkah perhitungan Trip Assignment dengan Metode Smock :

1. Menentukan volume kendaraan maksimum (skr/jam) pada jalan eksisting.

2. Menentukan besarnya increment setiap iterasi.

3. Menentukan kecepatan rata-rata pada ruas jalan eksisting maupun jalan tol.

4. Menentukan panjang jalan eksisting dan panjang jalan tol yang bersangkutan.

5. Menentukan Travel Time (TT) dalam satuan menit pada setiap jalan eksisting maupun pada jalan tol. Untuk jalan eksisting, waktu tempuh didapatkan dari membagi panjang jalan dengan kecepatan rata-rata tempuh kemudian dijadikan satuan menit. Sedangkan untuk jalan tol, waktu tempuh didapatkan dari membagi panjang jalan dengan kecepatan rata-rata arus bebas ditambah dengan hasil pembagian dari tarif tol dengan nilai waktu kemudian dijadikan satuan menit.

6. Menentukan kapasitas jalan (C) setiap jalan eksisting maupun jalan tol yang telah ditentukan.

7. Pada iterasi pertama dimasukkan rata-rata volume sepeda motor sebagai perbandingan antara jalan eksisting dan jalan tol.

8. Dari hasil besarnya travel time setiap iterasi ini selanjutnya dibandingkan antara ruas jalan eksisting dan jalan tol. Dari hasil perhitungan tersebut didapatkan porsentase sebagaimana pada Tabel 4. berikut :

Tabel 4.

Presentase Perpindahan Kendaraan Berdasarkan Metode Smock

\begin{tabular}{ccccc}
\hline \hline Asal & Tujuan & Arah & $\begin{array}{c}\text { Tidak } \\
\text { Pindah }\end{array}$ & Pindah \\
\hline $\begin{array}{c}\text { Ruas A } \\
\text { dan }\end{array}$ & Jalan Tol & Malang-Pandaan & $40.00 \%$ & $60.00 \%$ \\
Ruas B & Seksi 1 & Pandaan-Malang & $22.22 \%$ & $77.78 \%$ \\
Ruas C & Jalan Tol & Malang-Pandaan & $40.00 \%$ & $60.00 \%$ \\
& Seksi 2 & Pandaan-Malang & $44.44 \%$ & $55.56 \%$ \\
Ruas D & Jalan Tol & Malang-Pandaan & $40.00 \%$ & $60.00 \%$ \\
& Seksi 3 & Pandaan-Malang & $40.00 \%$ & $60.00 \%$ \\
Ruas E & Jalan Tol & Malang-Pandaan & $40.00 \%$ & $60.00 \%$ \\
& Seksi 4 & Pandaan-Malang & $40.00 \%$ & $60.00 \%$ \\
Ruas F & Jalan Tol & Malang-Pandaan & $46.15 \%$ & $53.85 \%$ \\
& Seksi 5 & Pandaan-Malang & $70.00 \%$ & $30.00 \%$ \\
\hline \hline
\end{tabular}


Perhitungan nantinya akan digunakan untuk menghitung volume kendaraan yang berpindah dari jalan eksisting ke jalan tol.

\section{Analisis Lalu Lintas Kondisi with Project}

Tabel 5.

Derajat kejenuhan Jalan Tol Pandaan - Malang with Project

\begin{tabular}{llccc}
\hline \multicolumn{1}{c}{ Ruas Jalan } & \multicolumn{1}{c}{ Arah } & $\mathrm{Q}$ & $\mathrm{C}$ & $\mathrm{Dj}$ \\
\hline SEKSI 1(Pandaan- & Malang-Pandaan & 630 & 4655 & 0.14 \\
Purwodadi) & Pandaan-Malang & 760 & 4655 & 0.16 \\
SEKSI 2(Purwodadi- & Malang-Pandaan & 1082 & 4655 & 0.23 \\
Lawang) & Pandaan-Malang & 646 & 4655 & 0.14 \\
SEKSI 3(Lawang- & Malang-Pandaan & 1359 & 4655 & 0.29 \\
Singosari) & Pandaan-Malang & 1477 & 4655 & 0.32 \\
Seksi 4(Singosari- & Malang-Pandaan & 1239 & 4655 & 0.27 \\
Pakis) & Pandaan-Malang & 1257 & 4655 & 0.27 \\
SEKSI 5(Pakis- & Malang-Pandaan & 852 & 4655 & 0.18 \\
Malang) & Pandaan-Malang & 368 & 4655 & 0.08 \\
\hline \hline
\end{tabular}

Dari hasil perhitungan trip assignment maka akan didapatkan presentase kendaraan yang akan berpindah ke jalan tol dan kendaraan yang tetap menggunakan jalan eksisting sehingga dapat diketahui jumlah arus lalu lintas yang akan melewati Jalan Tol Pandaan - Malang. Setelah didapatkan jumlah arus lalu lintas yang melewati jalan tol dan telah dilakukan perhitungan kapasitas jalan tol, maka dapat diketahui besarnya derajat kejenuhan pada jalan tol rencana sebagaimana pada Tabel 5.

\section{E. Analisis Biaya Operasinal Kendaraan}

Perhitungan Biaya Operasional Kendaraan (BOK) pada studi ini menggunakan metode Jasa marga. BOK terdiri dari biaya tidak tetap (variable cost): biaya konsumsi bahan bakar, biaya pelumas, biaya ban, biaya pemeliharaan (suku cadang), biaya pemeliharaan (upah mekanik), dan biaya tetap (fixed cost): biaya depresiasi kendaraan, biaya bunga modal, dan biaya over head [5]. Parameter yang digunakan dalam perhitungan biaya operasional kendaraan adalah harga dari tiap-tiap komponen pada berbagai jenis kendaraan dan kecepatan dari tiap jenis kendaraan. Berikut ini adalah asumsi yang dipakai untuk tiap-tiap jenis golongan kendaraan beserta harga satuan yang digunakan dalam perhitungan BOK.

a.

Golongan I (mobil penumpang, bus, elf)

$>$ Tipe Kendaraan

:Grand New Avanza

Type $1.3 \mathrm{E}$

- Harga Kendaraan

: Rp. 191.100.000

- Bahan Bakar

- Pelumas

- Tipe Ban

- Harga Ban

- Biaya Pemeliharaan

: Rp. 7.800,00 (Pertalite)

: Rp. 69.000,00 (Castrol)

: Bridgestone

: Rp. 828.000,00 / ban

: Rp. 15.000,00 / jam

: Isuzu Elf NLR 55 B

Microbus

- Harga Kendaraan

- Bahan Bakar

- Pelumas

- Tipe Ban

- Harga Ban

- Biaya Pemeliharaan

Tipe Kendaraan

- Harga Kendaraan

- Bahan Bakar

- Pelumas

- Tipe Ban

- Harga Ban

: Rp. 9.500,00 (Biosolar)

: Rp. 50.000,00 (Cartago)

: Bridgestone

: Rp. 1.059.000,00 / ban

: Rp. 15.000,00 / jam

: Hino A215

: Rp. 545.000 .000

: Rp. 9.500,00 (Biosolar)

: Rp. 50.000,00 (Cartago)

: Dunlop

: Rp. 1.260.000,00 / ban b.

- Biaya Pemeliharaan

bolongan II (truk 2 As)

$>$ Tipe Kendaraan : Hino dutro 110 LD

- Harga Kendaraan

- Bahan Bakar

- Pelumas

- Tipe Ban

- Harga Ban

- Biaya Pemeliharaan

c. Golongan III (Truk 3 As)

$>$ Tipe Kendaraan

- Harga Kendaraan

- Bahan Bakar

- Pelumas

- Tipe Ban

- Harga Ban

: Rp. 248.400.000

: Rp. 9.500,00 (Biosolar)

: Rp. 50.000,00 (Cartago)

: Dunlop

: Rp. 1.059.000,00 / ban

: Rp. 15.000,00 / jam

: Hino FL235JN

: Rp. 660.000 .000

: Rp. 9.500,00 (Biosolar)

: Rp. 50.000,00 (Cartago)

: Dunlop

- Biaya Pemeliharaan : Rp. 15.000,00 / jam

d. Golongan IV (Truk 4 As)

$>$ Tipe Kendaraan : Hino SG 260J ABS

- Harga Kendaraan : : Rp. 677.000 .000

- Bahan Bakar : : Rp. 9.500,00 (Biosolar)

- Pelumas : : Rp. 50.000,00 (Cartago)

- Tipe Ban

- Harga Ban

: Dunlop

- Biaya Pemeliharaan

e. Golongan V (Truk 5 As)

$>$ Tipe Kendaraan : Hino TH C/R ABS

- Harga Kendaraan : : Rp. 917.000 .000

- Bahan Bakar : : Rp. 9.500,00 (Biosolar)

- Pelumas : : Rp. 50.000,00 (Cartago)

- Tipe Ban

: Dunlop

- Harga Ban

: Rp. 1.260.000,00 / ban

- Biaya Pemeliharaan : Rp. 15.000,00/ jam

Dengan menggunakan formula jasa marga, maka total BOK didapatkan dengan cara:

Total BOK =Total Biaya Gerak (konsumsi BBM + Konsumsi oli mesin + pemakaian ban + Depresiasi) + Total biaya tetap (biaya bunga Modal + baya asuransi)

Dan cara menghitung total biaya operasional adalah

Total $=$ Harga BOK $(\mathrm{Rp} / \mathrm{km}) *$ Jarak $(\mathrm{km}) *$ Volume Kendaraan (skr/tahun)

\section{F. Nilai Waktu}

Nilai waktu merupakan besarnya jumlah uang yang dikeluarkan oleh pengguna jalan untuk melakukan satu unit waktu perjalanan secara ekonomis [5]. Besarnya nilai keuntungan (benefit) dari nilai waktu diperoleh dari perhitungan nilai penghematan (saving) nilai waktu. Untuk mendapatkan nilai penghematan nilai waktu yaitu dengan cara membandingkan nilai waktu sebelum ada jalan tol (without project) dengan nilai waktu sesudah ada jalan tol (with project). Untuk mendapatkan nilai waktu digunakan rumus:

Nilai Waktu $=$ Max $\{(\mathrm{k}+$ Nilai Waktu Dasar $*$ faktor kalibrasi); (Nilai Waktu Minimum * faktor kalibrasi)\}

Sehingga dapatkan nilai waktu tiap golongannya:

- Gol. I = Rp. 70.923

- Gol. IIA = Rp. 106.983

- Gol. IIB = Rp. 79.472

Nilai waktu pada umur rencana mengalami kenaikan inflasi sebesar 4,25\% yang didapatkan dari rata-rata kenaikan 
inflasi selama 3 tahun belakangan ini. Data inflasi ini didapatkan dari website resmi Bank Indonesia (www.bi.go.id). Nilai inflasi digunakan untuk perhitungan selama 35 tahun ke depan. Selanjutnya nilai waktu dikalikan dengan waktu tempuh perjalanan untuk mendapatkan nilai waktu pada satu tahun.

Nilai Waktu $=$ Waktu Tempuh $\mathrm{x}$ Nilai Waktu $\mathrm{x}$ Jumlah Kendaraan x 365 hari

\section{G. Analisis Kelayakan Ekonomi}

Analisis kelayakan ekonomi keuntungan ditinjau dari sudut pandang kebermanfaatnya terhadap masyarakat sebagai pengguna jalan (user cost). Dalam analisis ini kelayakan dinilai dari parameter NPV (Net Present Value) dan BCR (Benefit Cost Ratio) selama umur rencana. Nilai manfaat didapatkan dari jumlah penghematan (saving) Biaya Operasional Kendaraan (BOK) dan penghematan (saving) nilai waktu sebelum dan sesudah adanya proyek pembangunan Jalan Tol Pandaan - Malang. Sedangkan biaya investasi pembangunan jalan tol ini berupa biaya konstruksi dan biaya pembebasan lahan, serta biaya operasional dan pemeliharan.

\section{Saving BOK}

Penghematan Biaya Operasional Kendaraan merupakan perbandingan besarnya nilai BOK pada kondisi without project dan kondisi with project. Kondisi without project adalah sebuah kondisi sebelum dibangunnya Jalan Tol Pandaan - Malang sedangkan kondisi with project adalah sebuah kondisi setelah dibangunnya Jalan Tol Pandaan Malang. Perhitungan penghematan BOK didapatkan dari:

Total BOKwithout project $=$ BOK semua Ruas jalan eksisting without project

Total BOKwith project $=$ BOKsemua ruas jalan eksisting with project + BOK Jalan Tol Pandaan - Malang

Saving BOK $=$ BOKwithout project - BOKwith project

Sehingga didapatkan penghematan pada tahun 2054 sejumlah Rp1.668.479.397.334

\section{Saving Nilai Waktu}

Penghematan Nilai Waktu merupakan perbandingan antara besarnya nilai waktu pada kondisi without project dan kondisi with project. Kondisi without project adalah sebuah kondisi sebelum dibangunnya Jalan Tol Pandaan - Malang sedangkan kondisi with project adalah sebuah kondisi setelah dibangunnya Jalan Tol Pandaan - Malang. Untuk mengetahui berapa penghematan dari nilai waktu proyek menggunakan rumus: $\begin{aligned} \text { Saving Nilai Waktu }= & \text { Nilai Waktu }(\text { without project })-\text { Nilai } \\ & \text { Waktu }(\text { with project })\end{aligned}$

Sehingga didapatkan penghematan nilai waktu pada tahun 2054 sejumlah Rp1.534.310.267.889

Kelayakan Ekonomi

Dalam analisis ini kelayakan dinilai dari parameter NPV (Net Present Value) dan BCR (Benefit Cost Ratio). Selama umur rencana, kedua parameter tersebut didapat dari membandingkan antara nilai manfaat dan biaya pembangunan Jalan Tol Pandaan - Malang.
Hasil perhitungan kelayakan ini diberikan dalam bentuk cashflow selama 35 tahun yang akan menghasilkan perhitungan untung rugi di setiap tahun rencana dari sudut pandang pengguna jalan. Nilai investasi dan biaya pemeliharaan yaitu:

- Biaya Investasi = Rp 5.970.055.000.000

- Biaya Pemeliharaan = Rp. 82.292.000.000

- Tingkat Suku Bunga $=4,86 \%$ (BI rate) flat .

Kemudian setelah dilakukan perhitungan didapatkan:

- Benefit= Rp24.181.721.363.481

- Cost = Rp8.649.848.530.752

Sehingga didapatkan nilai BCR:

$\mathrm{BCR}=\mathrm{Rp} 24.181 .721 .363 .481 / \mathrm{Rp} 8.649 .848 .530 .752$ $=2,796>1$

Dan nilai NPV:

$\mathrm{NPV}=\mathrm{Rp} 24.181 .721 .363 .481-\mathrm{Rp} 8.649 .848 .530 .752$

$=\operatorname{Rp} 15.531 .872 .832 .729>0$

Maka dapat disimpulkan bahwa pembangunan Jalan Tol Pandaan - Malang dikatakan "LAYAK" secara ekonomi.

\section{H. Analisis Kelayakan Finansial}

Analisis kelayakan finansial keuntungan ditinjau dari sudut pandang investor sebagai pihak yang memberi investasi terhadap biaya pembangunan Jalan Tol Pandaan - Malang. Untuk menentukan analisis kelayakan finansial dapat ditentukan dari beberapa indikator seperti Benefit Cost Ratio (BCR), Net Present Value (NPV), Payback Period, dan Internal Rate of Return (IRR). Dalam perhitungan kelayakan finansial proyek, maka perlu dicari :

1. Pendapatan Tarif Tol Pandaan - Malang

Tarif tol yang digunakan untuk Tol Pandaan - Malang berdasarkan hasil interpolasi tarif Tol Solo - Ngawi Segmen Kertasura Sragen berdasarkan Badan Pengatur Jalan Tol (BPJT) (dengan panjang 35,2 km) sesuai dengan panjang Jalan Tol Pandaan - Malang.

Golongan I = Rp. $1.000,00 / \mathrm{km}$

Golongan II = Rp. $1.600,00 / \mathrm{km}$

Golongan III = Rp. $1.600,00 / \mathrm{km}$

Golongan IV = Rp. $2.100,00 / \mathrm{km}$

Golongan V = Rp. $2.100,00 / \mathrm{km}$

Kemudian didapatkan total pendapatan tarif tol pada tahun 2054 sebagaimana pada Tabel 6.

Tabel 6.

Total Pendapatan Tarif Tol pada Tahun 2054

\begin{tabular}{crr}
\hline \hline Jalan Tol Pandaan - Malang & & Tol Pendapatan \\
\hline Seksi 1 & $\mathrm{Rp}$ & $2,440,738,351,000$ \\
Seksi 2 & $\mathrm{Rp}$ & $1,674,451,754,000$ \\
Seksi 3 & $\mathrm{Rp}$ & $2,319,436,405,000$ \\
Seksi 4 & $\mathrm{Rp}$ & $1,366,613,135,000$ \\
Seksi 5 & $\mathrm{Rp}$ & $442,880,242,000$ \\
\hline \hline
\end{tabular}

2. Analisis Kelayakan Finansial BCR dan NPV

Dalam menganalisis kelayakan pembangunan Jalan Pandaan - Malang ditinjau dari aspek finansial, maka dibutuhkan analisis BCR dan NPV sebagai indikator layak atau tidaknya pembangunan Jalan Tol Pandaan - Malang.

Dari hasil analisis maka dapat disimpulkan:

- Benefit (Income) = Rp25.409.947.022.739

- Cost $($ Outcome) $=$ Rp8.649.848.530.752 
Sehingga hasilnya didapatkan sebagai berikut ini:

$$
\begin{aligned}
\mathrm{BCR} & =\mathrm{Rp} 25.409 .947 .022 .739 / \mathrm{Rp} 8.649 .848 .530 .752 \\
& =2,938>1 \\
\mathrm{NPV} & =\mathrm{Rp} 25.409 .947 .022 .739-\mathrm{Rp} 8.649 .848 .530 .752 \\
& =\mathrm{Rp} 16.760 .098 .491 .986>0
\end{aligned}
$$

Maka proyek pembangunan Jalan Tol Pandaan - Malang dikatakan "LAYAK" secara finansial.

3. Analisis Payback Period

Dalam analisis kelayakan finansial, maka perlu diketahui berapa lama jangka waktu pengembalian biaya investasi. Analisis ini dihitung dengan cara menghitung waktu yang diperlukan pada saat total arus kas masuk sama dengan arus kas keluar $(\mathrm{NPV}=0)$. Dari hasil perhitungan didapatkan waktu pengembalan investasi (Payback Period) selama 17 Tahun 6 Bulan 22 Hari

Payback Period < Lama konsesi = 35 Tahun

Maka proyek pembangunan Jalan Tol Pandaan - Malang dikatakan "LAYAK" secara finansial.

4. Analisis Kelayakan Finansial Internal Rate of Return

Analisis Internal Rate of Return merupakan tingkat pengembalian yang menghasilkan NPV arus kas masuk sama dengan NPV arus kas keluar. Analisis ini dilakukan dengan cara membandingkan tingkat suku bunga yang menyebabkan nilai NPV $=0$ dan tingkat suku bunga pengembalian terendah MARR (Minimum Attractive Rate of Return).

Dari hasil perhitungan didapatkan tingkat pengembalian suku bunga $($ IRR $)=11,926 \%$

IRR $>$ Discount Rate $=4,86 \%$

Maka proyek pembangunan Jalan Tol Pandaan - Malang dikatakan "LAYAK" secara finansial

\section{KESIMPULAN DAN SARAN}

\section{A. Kesimpulan}

Berdasarkan hasil perhitungan dan analisis, maka didapatkan kesimpulan bahwa:

1. Berdasarkan hasil analisis dan perhitungan volume without project dalam studi ini, maka didapatkan kondisi derajat kejenuhan (DS) pada jalan eksisting sebelum pembangunan Jalan Tol Pandaan - Malang pada tahun pertama.

- Jalan Raya Malang - Surabaya (Sukorejo) Arah Malang - Pandaan $=0,72$

- Jalan Raya Malang - Surabaya (Sukorejo) Arah Pandaan - Malang $=0,80$

- Jalan Raya Pasuruan (Purwosari) Arah Malang Pandaan $\quad=0,50$

- Jalan Raya Pasuruan (Purwosari) Arah Pandaan Malang $=0,51$

- Jalan Raya Gempol - Malang (Purwodadi) Arah Malang - Pandaan $=0,72$

- Jalan Raya Gempol - Malang (Purwodadi) Arah Pandaan - Malang = 0,58

- Jalan Raya Mondoroko (Singosari) Arah Malang Pandaan =0,99

- Jalan Raya Mondoroko (Singosari) Arah Pandaan Malang =0,97

- Jalan A. Yani Utara (Arjosari) Arah Malang Pandaan $=0,91$

- Jalan A. Yani Utara (Arjosari) Arah Pandaan Malang $=0,86$
- Jalan Raya Letjend S. Parman Arah Malang Pandaan = $=0,75$

- Jalan Raya Letjend S. Parman Arah Pandaan Malang $=0,61$

2. Berdasarkan hasil analisis dan perhitungan trip assignment dengan metode smock maka didapatkan persentase volume kendaraan yang akan pindah ke Jalan Tol Pandaan - Malang :

- Dari Jalan Raya Malang - Surabaya (Sukorejo) dan Jalan Raya Pasuruan (Purwosari) ke Jalan Tol Seksi 1 Arah Malang - Pandaan $=60 \%$

- Dari Jalan Raya Malang - Surabaya (Sukorejo) dan Jalan Raya Pasuruan (Purwosari) ke Jalan Tol Seksi 1 Arah Pandaan - Malang $\quad=77,78 \%$

- Dari Jalan Raya Gempol - Malang (Purwodadi) ke Jalan Tol Seksi 2 Arah Malang - Pandaan $=60 \%$

- Dari Jalan Raya Gempol - Malang (Purwodadi) ke Jalan Tol Seksi 2 Arah Pandaan - Malang = 55,56\%

- Dari Jalan Raya Mondoroko (Singosari) ke Jalan Tol Seksi 3 Arah Malang - Pandaan $=60 \%$

- Dari Jalan Raya Mondoroko (Singosari) ke Jalan Tol Seksi 3 Arah Pandaan - Malang =60\%

- Dari Jalan A. Yani Utara (Arjosari) ke Jalan Tol Seksi 4 Arah Malang - Pandaan $\quad=60 \%$

- Dari Jalan A. Yani Utara (Arjosari) ke Jalan Tol Seksi 4 Arah Pandaan - Malang =60\%

- Dari Jalan Raya Letjend S. Parman ke Jalan Tol Seksi 5 Arah Malang - Pandaan $=53,85 \%$

- Dari Jalan Raya Letjend S. Parman ke Jalan Tol Seksi 5 Arah Pandaan - Malang $=30 \%$

3. Berdasarkan hasil analisis dan perhitungan volume with project dalam studi ini, maka didapatkan kondisi derajat kejenuhan (DS) pada jalan tol rencana setelah pembangunan jalan tol Pandaan - Malang pada tahun pertama.

- Seksi 1 (Pandaan - Purwodadi) Arah Malang Pandaan $=0,14$

- Seksi 1 (Pandaan - Purwodadi) Arah Pandaan Malang $=0,16$

- Seksi 2 (Purwodadi - Lawang) Arah Malang Pandaan $=0,23$

- Seksi 2 (Purwodadi - Lawang) Arah Pandaan Malang $=0,14$

- Seksi 3 (Lawang - Singosari) Arah Malang Pandaan $=0,29$

- $\quad$ Seksi 3 (Lawang - Singosari) Arah Pandaan Malang $=0,32$

- Seksi 4 (Singosari - Pakis) Arah Malang - Pandaan $=0,27$

- $\quad$ Seksi 4 (Singosari - Pakis) Arah Pandaan-Malang $=0,27$

- $\quad$ Seksi 5 (Pakis - Malang) Arah Malang - Pandaan $=0,18$

- $\quad$ Seksi 5 (Pakis - Malang) Arah Pandaan - Malang $=0,08$

4. Dari analisis aspek kelayakan ekonomi didapatkan hasil:

- Benefit $=\operatorname{Rp} 24.181 .721 .363 .481$

- Cost $=$ Rp 8.649.848.530.752

Sehingga didapatkan Nilai Beneft Cost Ratio (BCR) $2,796>1$ dan nilai Nett resent Value (NPV) Rp. 15.531.872.832.729 >0 sehingga dapat disimpulkan bahwa 
pembangunan Jalan Tol Pandaan - Malang dikatakan "LAYAK" secara ekonomi.

5. Dari analisis aspek kelayakan finansial bedasarkan data volume hasil perhitungan trip assignment, didapatkan hasil:

- Benefit $_{(\text {Income) }} \quad=$ Rp25.409.947.022.739

- $\operatorname{Cost}_{\text {(Outcome) }}=\mathrm{Rp} 8.649 .848 .530 .752$

Sehingga didapatkan nilai Benefit Cost Ratio (BCR): 2,938>1 Nilai Nett Present Value (NPV): Rp 16.760.098.491.986 > 0. Dan nilai Internal Rate of Return (IRR): 11,926\% > 4,86\%, serta Payback Period: 17 Tahun 6 Bulan 22 Hari < 35 Tahun. Sehingga dapat disimpulkan bahwa pembangunan Jalan Tol Pandaan Malang dikatakan "LAYAK" secara finansial.

B. Saran

Hasil analisis dan perhitungan studi ini menunjukkan bahwa pembangunan Jalan Tol Pandaan - Malang dinyatakan layak dari segi ekonomi dan finansial, sehingga proyek ini diharapkan segera diselesaikan agar mampu mengatasi masalah kepadatan lalu lintas.

\section{DAFTAR PUSTAKA}

[1] BPS, "Badan Pusat Statistik Provinsi Jawa Timur," 2019. [Online]. Available:

https://jatim.bps.go.id/statictable/2018/10/29/1324/jumlahpenduduk-dan-laju-pertumbuhan-penduduk-menurut-kabupatenkota-di-provinsi-jawa-timur-2010-2016-dan-2017.html. [Accessed: 16-Feb-2018].

[2] BPS, "Badan Pusat Statistik," 2014. [Online]. Available: https://www.bps.go.id/statictable/2014/02/18/1274/proyeksipenduduk-menurut-provinsi-2010---2035.html. [Accessed: 17-Feb2018].

[3] Malang Times.com, "Jumlah Kunjungan Wisatawan di Kabupaten Malang Capai 5,8 Juta," 2017. [Online]. Available: https:/www.malangtimes.com/baca/20126/20170812/125427/wowjumlah-kunjungan-wisatawan-di-kabupaten-malang-capai-58-juta/. [Accessed: 18-Feb-2018].

[4] Kementerian Pekerjaan Umum, Pedoman Kapasitas Jalan Indonesia. Jakarta: Kementerian Pekerjaan Umum, 2014.

[5] Tamin, Ofyar Z. Perencanaan dan Permodelan Transportasi, 2nd ed. Bandung: ITB, 2000. 